\title{
GRANULOMA FORMATION AND ARTERIAL THROMBOSIS FOLLOWING COTTON WRAPPING OF AN INTRACRANIAL ANEURYSM
}

\author{
A CASE REPORT
}

ALEXANDRE VARELLA GIANETTI * - FRANCISCO OTAVI ANO LIMA PERPETUO **

SUMMARY - The authors report the case of a patient whose left middle cerebral artery aneurysm was wrapped with cotton. Occlusion of the middle cerebral artery, probably secondary to a foreign-body inflammatory reaction, developed late in the postoperative course. A computerized tomography scan revealed cerebral infarct, and an enhancing expansive lesion at the site of the aneurysm suggesting the formation of a granuloma. These findings are discussed and the literature is reviewed.

KEY WORDS: intracranial aneurysm wrapping (cotton), foreign-body granuloma, arterial thrombosis.

Formação de granuloma e trombose arterial após envolvimento de aneurisma intracraniano com algodão: relato de caso.

RESUMO - Os autores descrevem o caso de um paciente cujo aneurisma da artéria cerebral média esquerda foi envolvido com algodão. Oclusão da artéria cerebral média, provavelmente devida a reação inflamatória de tipo corpo estranho, desenvolveu-se tardiamente no curso pós-operatório. Tomografia computadorizada revelou infarto cerebral e uma lesão expansiva, que aumentava de densidade após injeção de contraste, no local do aneurisma, sugerindo formação de granuloma. Estes achados são discutidos e a literatura é revista.

PALAVRAS-CHAVE: envolvimento de aneurisma intracraniano (algodão), granuloma tipo corpo-estranho, trombose arterial.

Clipping of the aneurysmal neck is generally regarded as the best procedure for treating intracranial aneurysms. However, surgeons are often confront ted with aneurysms that cannot be clipped, either because of a broad base or arteriosclerotic plaques, or because they are fusiform or important vessels originate from them. In these cases, wrapping of the aneurysm is the method usually resorted to. Various types of materials have been used for wrapping, including acrylic2,3,4,6^ muscle7-9, fascia ${ }^{2} .^{4}$, cotton9, gauze1.4,13, muslin5.7,8 $n d$ biological glue 12.

This report concerns a patient that developed a granulomatous foreign-body reaction and thrombosis of the middle cerebral artery after an aneurysm of this artery was wrapped with cotton. This is a rare complication, of which very few examples are found in the literature.

Departamento de Psiquiatria e Neurologia da Universidade Federal de Minas Gerais: * Médico Residente; ** Professor Adjunto.

Dr. Francisco Otaviwno Lima Perpetuo - Rua Santa Catarina 1313/801 - 30180 Belo Horizonte MG - Brasil. 


\section{CASE REPORT}

GMD, a 40-year-old male with a history of mild hypertension and asthma awoke on November 30, 1989 with headache, photophobia and vomiting. On admission to the hospital on December 3, 1989, these symptoms persisted, and only nucal ridigity was observed on physical examination. The results of laboratory examinations (blood cell count, coagulogram, quantitative analyses of blood glucose, ions, urea, creatinine, uric acid, calcium, bilirubin, alkaline phosphatase) were normal. There was a sligth increase in transaminases (SGOT 90 UI/D, SGTP 79 UI/L). A computerized tomography (CT) scan performed on December 6, 1989 revealed blood in the left sylvian fissure. Bilateral carotid and left vertebral angiography showed dilation of the left middle cerebral artery trifurcation (Fig. 1). A left frontotemporal craniotomy was performed on December 19, 1989. During dissection of the middle cerebral artery and its trifurcation, transient local vasospasm was noted and reverted with the use of topical papaverine. The trifurcation of the middle cerebral artery was seen to be dilated, with a small, reddish weakened area, yet no true saccular aneurysm was identifiable. The adjacent brain tissue was xanthochromic. The trifurcation was wrapped with papaverinesoaked cotton. The patient had an uneventful postoperative course and was discharged on December 22, 1989. Fifteen days later, he experienced repeated episodes of right-sided weakness associated with dysphasia, which resolved completely. On March 11, 1990 he developed progressive loss of motor power on the right side and difficulty in talking, but there was no headache. Upon readmission, he was alert and showed nonfluent dysphasia, right-sided hemiparesis involving predominantly the face and arm, hyperreflexia, and a right Babinski sign. Nucal ridigity was not observed. A CT scan revealed a low-density area in the left basal ganglia region causing compression of ipsilateral lateral ventricle, in addition to a high-density, homogeneously-enhanced mass in the anterior part of the left sylvian fissure (Fig. 2). Left carotid angiography showed occlusion of the trunk of the left middle cerebral artery (Fig. 3). Retrograde filling of the branches of the middle cerebral artery was evident on the late phase of the injection. The bifurcation of the left common carotid artery was also studied, but no changes were found. Treatment with physiological Rheomacrodex was

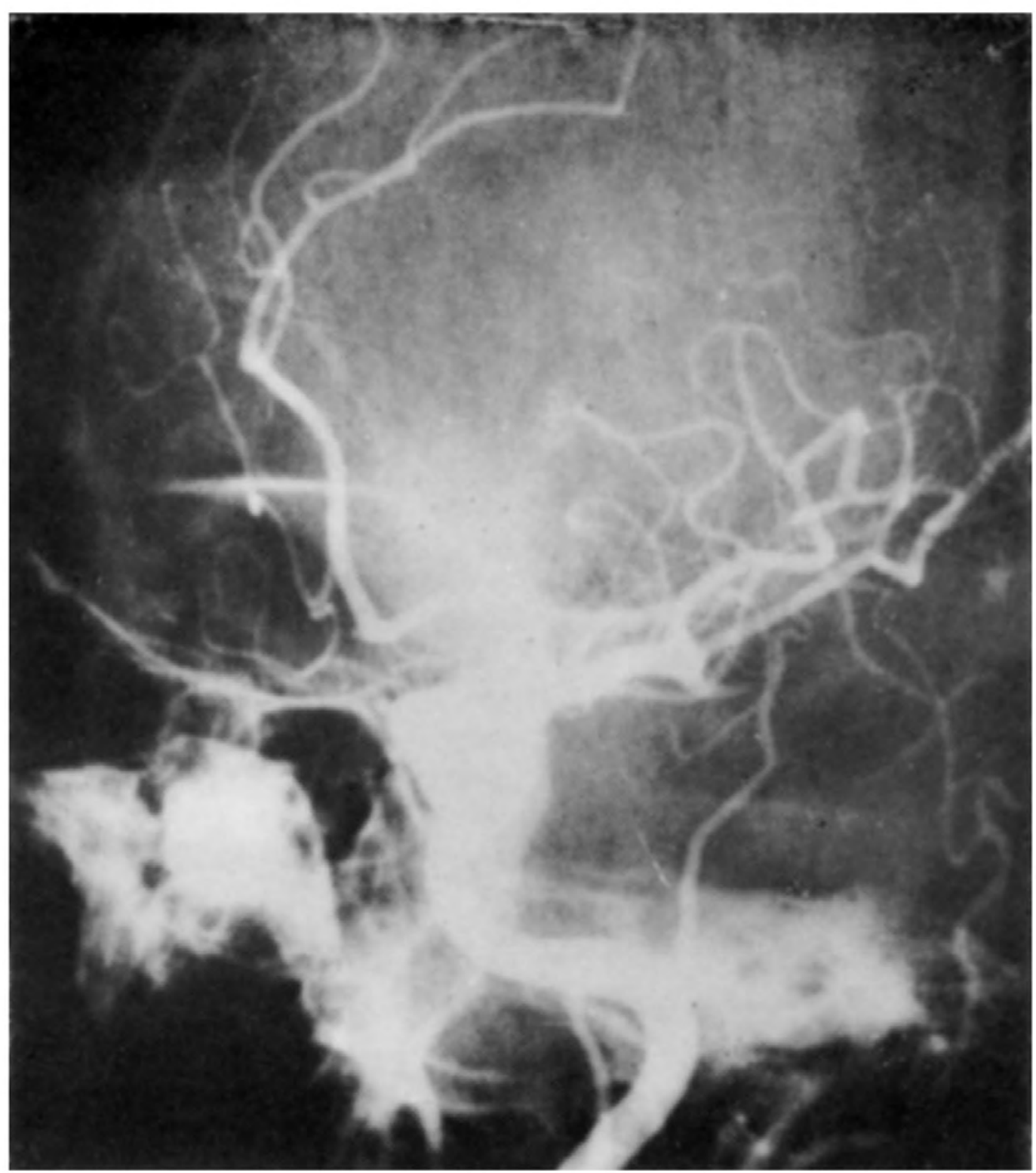

Fig. 1. Case GMD. Preoperative left carotid angiogram in oblique viaw showing dilation of the left middle cerebral artery trifurcation. 

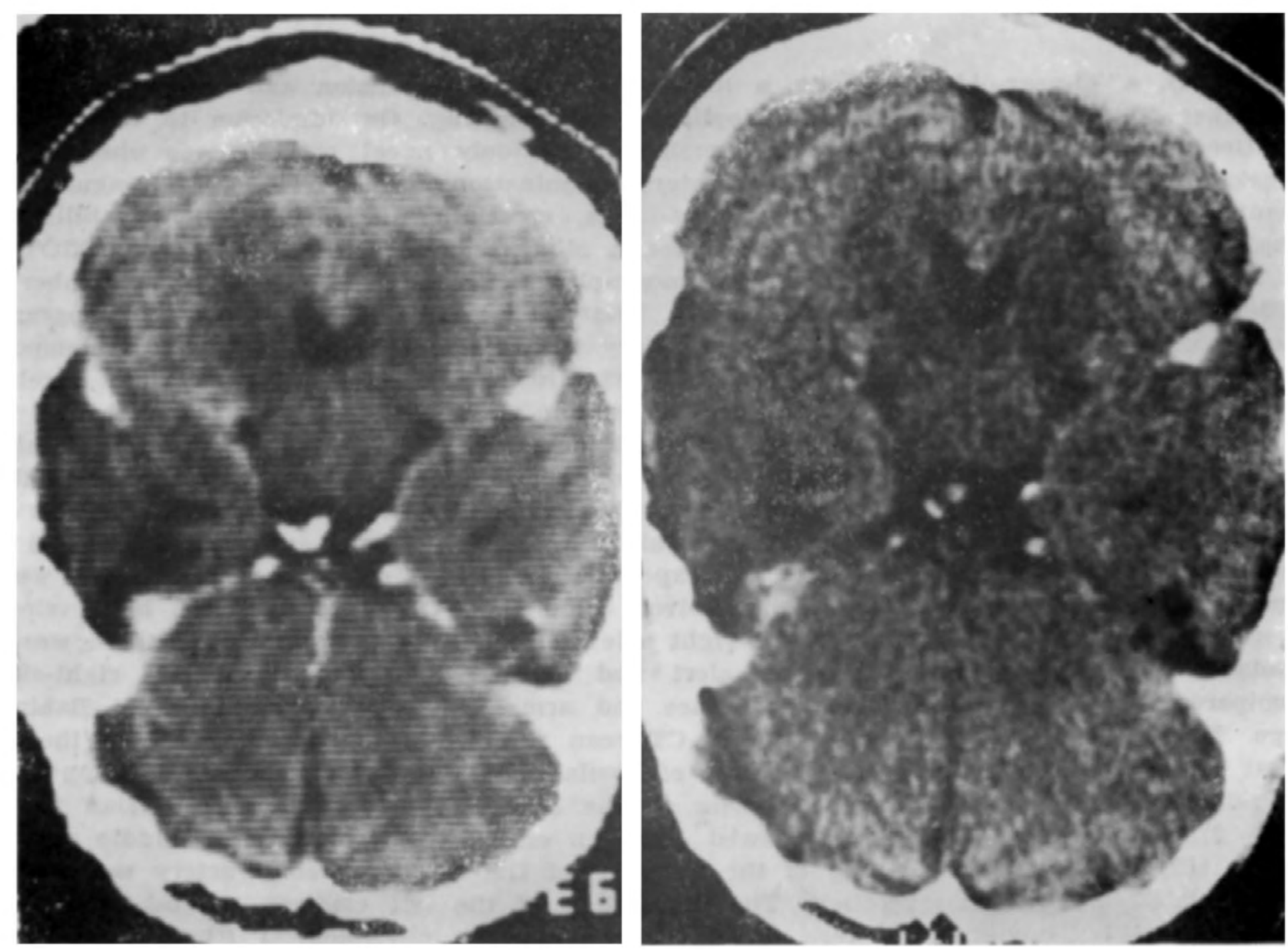

Fig. 2. Case GMD. Computerized tomography scan before (left) and after contrast injection (right) showing a high density contrast enhancing mass in the anterior part of the left sylvian fissure.

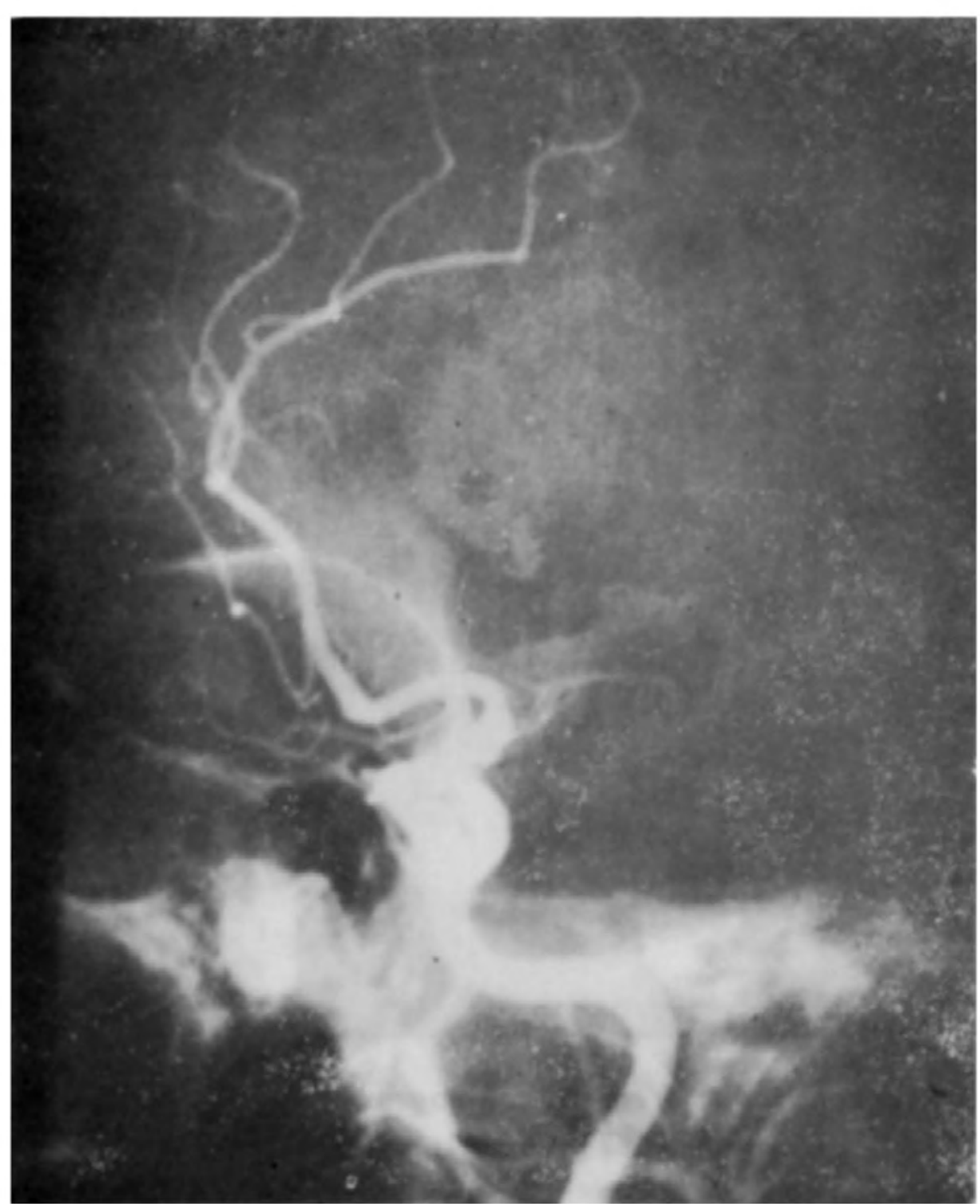

Fig. 3. Cillse GMD. Postoperative left carotid angiogram in oblique view showing occlusion of the trunk of the left middle cerebral artery. 
started. Although the patient remained alert and had no nucal ridigity, the motor deficit increased. Under treatment with heparin (4000 U IV at 4-hour intervals), started on March 3, 1990, he began improving. Héparine was administered during a 14-day period. At the time of discharge, the patient shewed discrete dysnomia and the hemiparesis was less severe than on admission. A follow-up CT scan performed one month after readmission showed that the enhancing expansive lesion in the sylvian fissure had not changed in size or shape.

\section{COMMENT'S}

Various biological and/or synthetic materials, among which muscle ${ }^{70}$, fascia2,4, cotton', gauze 1.4,13, muslin5,7,8, biological glue 12 and acrylic2-4,6, have been used for the wrapping or wall reinforcement of unclippable aneurysms. None of these materials, however, offers the ideal properties of immediate adherence, long term effectiveness, and no toxicity. Laboratory and clinicopathological studies conducted by Sachs' showed that a marked fibrotic reaction is induced when cotton is wrapped around intracranial vessels in dogs and humans. Sturdy et al.n also demonstrated that various substances, including cotton, talcum powder, and suture material, are capable of eliciting a granulomatouos reaction. What appears to have occurred in the case reported here was an exaggerated tissue reaction to the foreign body (cotton), leading to the formation of a giant granuloma and to arterial occlusion.

Vascular thrombosis resulting from the coating of an aneurysm with fascia and cyanoacrylate was demonstrated by Coe and Bondurant ${ }^{2}$. These authors suggested that shrinking of the fascia and acrylic coating could, in that case, have been responsible for occlusion of the vessel.

A few reports concerning giant granulomas are available in the literature. Shinosaka and Wagaio described the development of a granulomatous lesion after the resection of a meningioma. Haisa et al. ${ }^{5}$ reported granuloma formation after muslin wrapping and cyanoacrylate coating of an aneurysm. In a recent report, Chambi et al.i described six female patients with gauze-induced lesions (termed «gauzomas»), 'adding to three other cases, also all female, already identified in the literature. All underwent aneurysm reinforcement with gauze and developed enhancing expansive lesions in correspondence with CT-demonstrated sites of aneurysm. In this series of patients, signs and symptoms developed progressively within 17 months of the surgery. They included headache, low grade fever, epilepsy, endocrinopathy, cerebrospinal fluid pleocytosis, and cranial nerve deficit. In none of these cases, however, were ischemic infarcts or arterial occlusion reported. The reaction was self-limiting in all cases, and some patients even made a partial recovery. Anatomopathological examination was made in only one patient and revealed an area of fibrotic granulomatous foreignbody reaction containing biréfringent material.

The presence of fever and cerebrospinal fluid pleocytosis in some patients, plus a contrast-enhancing mass on $C T$, sugests an inflammatory process. It is also suspected that vascular changes are produced that could explain the appearence of seizures and cranial nerves damage. In the case reported here, the inflammatory reaction is believed to have extended throughout the wall of the left middle cerebral artery producing its occlusion.

\section{REFERENCES}

1. Chambi I, Tasker RR, Gentili F. Gaze-induced granuloma («gaumoman)): an uncommon complication of gaze reinforcement of berry aneurysms. J Neurosurg 1990, 72:163-170.

2. Coe JE, Bondurant CP. Late thrombosis following the use of autogenous fascia and a cyanoacrylate (Eastman 910 Monomer) for the wrapping of an intracranial aneurysm. J Neurosurg 1964, 21:884-886.

3. Dutton J. Acrylic investment of intracranial aneurysms: a report of 12 years' experience. J Neurosurg 1969, 31:652-657.

4. Kempe LG. Aneurysm, anterior part of the circle of Willis. In Kempe LP ((exdi)): Operative Neurosurgery. Berlin: Springer, 1985, 22-75.

5. Haisa T, Matsumiya K, Yoshimasu N. Foreign body granuloma as a complication of wrapping and coating an intracranial aneurysm: case report. J Neurosurg 1990, 72:202-294, 
6. Hayes GJ, Leaver RC. Methyl methacrylate investment of intracranial aneurysms: a report of seven years experience. J Neurosurg 1966, 25:79-80.

7. Mount LA, Antunes L. Results of treatment of intracranial aneurysms by wrapping and coating. J Neurosurg 1975, 42:189-193.

8. Pool JL. Muslin gaure in intracranial vascular surgery: technical note. J. Neurosurg 1976, 44:127-128

9. Sachs $\mathrm{E} \mathrm{Jr}$. The fate of muscle and cotton wrapped about intracranial carotid arteries and aneurysms: a laboratory and clinico-pathological study. Acta Neurochir 1972, 26:121137.

10. Shimosaka S, Waga S. Foreign-body granuloma simulating recurrence of falx meningioma: case report. J Neurosurg 1983, 50:1085-1087.

11. Sturdy JH, Baird RM, Gerein AN. Surgical sponges: a cause of granuloma and adhesion formation. Ann Surg 1967, 165:128-134.

12. Sugita K. Microsurgical Atlas. Berlin: Springer, 1985.

13. Taylor JC, Choudhury AR. Reinforcement with gauze wrapping for ruptured aneursyms of the middle cerebral artery. J Neurosurg 1977, 47:828-832. 